\title{
Cretaceous oblique detachment tectonics in the Fosdick Mountains, Marie Byrd Land, Antarctica
}

\author{
R. McFadden, ${ }^{1}$ C. S. Siddoway, ${ }^{2}$ C. Teyssier, ${ }^{1,3}$ C. M. Fanning, ${ }^{4}$ and S. C. Kruckenberg ${ }^{1}$ \\ 'Department of Geology \& Geophysics, University of Minnesota-Twin Cities, Minneapolis, MN 55455, USA [mcfad031@umn.edu, kruc0030@umn.edu] \\ 2Department of Geology, Colorado College, Colorado Springs, CO 80903, USA as above [csiddoway@coloradocollege.edu] \\ ${ }^{3}$ Institut de Geologie et de Paleontologie, Anthropole, Universite de Lausanne, CH-1015, Lausanne, Switzerland [teyssier@umn.edu] \\ ${ }^{4}$ Research School of Earth Sciences, Australia National University, Canberra, ACT 0200, Australia [mark.fanning@anu.edu.au]
}

\begin{abstract}
The Fosdick Mountains form an E-W trending migmatite dome in the northern Ford Ranges of Marie Byrd Land, Antarctica. Pervasively folded migmatites derived from lower Paleozoic greywacke and middle Paleozoic plutonic rocks constitute the dome. New field research documents a transition from melt-present to solid-state deformation across the south flank of the dome, and a mylonitic shear zone mapped for $30 \mathrm{~km}$ between Mt. Iphigene and Mt Richardson. Kinematic shear sense is dextral normal oblique, with top-to-the-SW and -WSW transport. A U-Pb age of $107 \mathrm{Ma}$, from a leucosome-filled extensional shear band, provides a meltpresent deformation age, and a $\mathrm{U}-\mathrm{Pb}$ age of $96 \mathrm{Ma}$, from a crosscutting granitic dike, gives a lower age limit for deformation. The shear zone, here named the South Fosdick detachment zone, forms the south flank of the migmatite dome and was in part responsible for the exhumation of mid-crustal rocks.
\end{abstract}

Citation: McFadden, R., C. S. Siddoway, C. Teyssier, C. M. Fanning, and S. C. Kruckenberg (2007), Cretaceous oblique detachment tectonics in the Fosdick Mountains, Marie Byrd Land, Antarctica, in Antarctica: A Keystone in a Changing World-Online Proceedings of the $10^{\text {th }}$ ISAES, edited by A. K. Cooper and C. R. Raymond et al., USGS OpenFile Report 2007-1047, Short Research Paper 046, 6 p.; doi:10.3133/of2007-1047.srp046

\section{Introduction}

The final event in breakup of the Gondwana supercontinent was rifting of the Mesozoic active margin in the Pacific sector. Onset of extension at circa $100 \mathrm{Ma}$ is recorded in the once contiguous parts of the margin Marie Byrd Land - New Zealand - Campbell Plateau by alkalic plutonism (Storey et al., 1998; Pankhurst et al., 1998; Siddoway et al., 2005), core complex formation (Tulloch and Kimbrough, 1989), and exhumation and rapid cooling of migmatite terrains (Richard et al., 1994; Siddoway et al. 2004a; Flowers et al., 2005). The Ross Sea extension has been attributed to detachment systems (Fitzgerald and Baldwin, 1997), and the presence of crustal-scale exhumation structures has been inferred for the most extensive exposure of high-grade rocks in West Antarctica, the Fosdick Mountains. Whereas the shear zones responsible for Cretaceous exhumation of mid-crustal rocks in South Island, New Zealand are wellexposed (Tulloch and Kimbrough, 1989; Scott and Cooper, 2006; Kula et al., 2007), the exhumation structures in West Antarctica have been elusive, with only cryptic information coming from drill hole (Fitzgerald and Baldwin, 1997), dredge, and airborne geophysical data (Luyendyk et al., 2003).

New investigations on the south flank of the Fosdick Mountains identify a through-going shear zone that accommodated dextral normal oblique sense of transport. This shear zone forms the extensive southern boundary of the Fosdick Mountains migmatite dome (Siddoway et al., 2004) and corresponds spatially and temporally to a transition in the conditions of deformation from melt-present (leucosome-filled shear bands; quartz interstitial to euhedral feldspar grains) to solidstate (mylonite gneiss and brittle shear fractures).

\section{The Fosdick Mountains}

The Fosdick Mountains (Fig. 1) form an elongate migmatite dome (Wilbanks, 1972; Siddoway et al., 2004), emplaced and cooled rapidly between 101-94 Ma (Richard et al., 1994). The footwall of the dome includes migmatitic gneisses and metaplutonic rocks that underwent plastic deformation at upper amphibolite grade and that preserve high temperature fabrics (Siddoway et al., 2004, 2005). The hanging wall consists of nonmetamorphosed Ford Granodiorite in the Chester Mountains, to the south, and the detachment zone consists of mylonitic gneisses that record transitional fabrics from melt-present to solid-state deformation.

\section{Footwall rocks - Fosdick migmatite dome}

The footwall of the Fosdick migmatite dome consists of numerous generations of leucogranitic sheets, dikes, and diatexite bodies that intruded $\mathrm{km}$-scale folds of pervasively folded paragneisses and granodioritic to leucogranitic intrusions (Fig. 2). The structurally deepest rocks define the diatexite core, exposed at the Ochs Glacier area (Fig. 1), which consists of felsic rocks with nebulitic and agmatitic migmatite structures (e.g., Mehnert, 1968). The upper part of the diatexite is affected by km-scale recumbent folds. Structurally above the diatexite, metatexite is pervasively folded at $100 \mathrm{~m}$ to $\mathrm{km}$-scale. Residual paragneisses are broadly interfolded with metaplutonic rocks. The paragneiss layers are internally deformed with $\mathrm{dm}$ - to $\mathrm{m}$-scale asymmetric folds. Gneissic, medium-grained biotite granite and megacrystic biotite granodiorite are foliated and locally mesoscopically folded. Preliminary U-Pb geochronological and isotope data (Siddoway et al., 2006) indicate that the metaplutonic phases are part of the of the regionally extensive Ford Granodiorite suite (Pankhurst et al. 1998) in Marie Byrd Land. Anatectic leucosome is ubiquitous in structural sites (e.g., Brown et al., 1994; Sawyer, 1994). Leucosome occupies layers concordant to metamorphic foliation, is entrained in folds, and accumulated in fold limbs, shear bands, and inter-boudin regions. Commonly, lower limbs of km-scale folds are strongly sheared and syntectonic leucogranite is localized in the sheared limbs. Above the metatexite is a leucogranitic sheeted complex that consists of narrow bands of paragneissic rocks intruded by sheeted leucogranitic rocks that have moderate to weak foliation, or lack visible fabrics. 


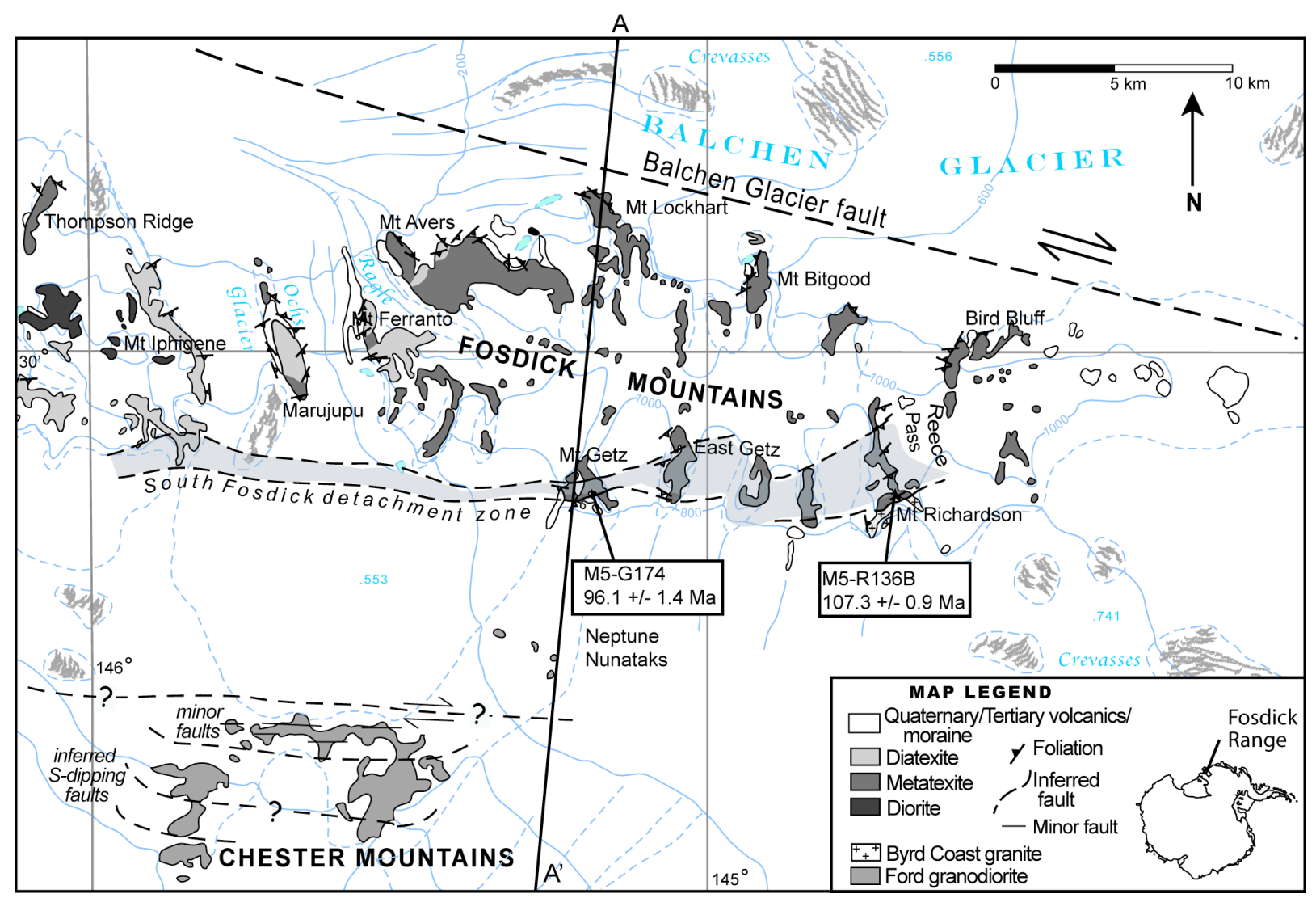

Figure 1. (A) Geologic map of the Fosdick Mountains in Marie Byrd Land, Antarctica. AA' is the line of the cross section in figure 2. Sample numbers and ages in boxes are locations of U-Pb SHRIMP zircon ages. Dashed lines mark the upper and lower boundaries of the South Fosdick detachment zone. The group of inferred and observed faults in the Chester Mountains dip moderately to the south, save for the structure bounding the north side of that range, which corresponds to a strong topographic and geophysical lineament (Luyendyk et al., 2003).

Throughout the dome, the migmatitic foliation generally strikes NE-SW and dips to the SE. The predominant preferred mineral alignment corresponds to biotite and sillimanite mineral stretching lineation that plunges shallowly to the SW. Foliation, mineral lineation, and fold axes orientations, associated with both "melt-present" and solid state fabrics, record normal oblique slip motion (Fig. 2a-e). Foliations in the diatexitic rocks are variable in attitude, but generally strike ENE, with shallow SSE dips (Fig. 2c). Poles to diatexite foliation define a fold axis that is oriented $(11,210)$ (plunge, trend). In metatexite of the northern range flank, the predominant foliation is SE dipping and the poles to foliation produce a NE fold axis with an orientation of $(10,065)$ (Fig. 2b). The biotite stretching lineation orientation is $(10,240)$, which is sub-parallel to the fold axis. The foliations in the metatexite on the south flank are predominantly ENE striking with a SSE dip. The biotite stretching lineations define a group at $(20,240)$, additionally, there is a suite of biotite lineations that display a preferred mineral alignment caused by crenulation cleavage, these lineation trends range from 140-250 (Fig. 2d). Structural features in the leucogranitic sheeted complex include rootless isoclinal folds, oblate boudin shapes, outcrop-scale leucosome-filled shear bands, and variably deformed mafic dikes. The foliations are subhorizontal with ENE-WSW strike and the predominant mineral stretching lineation is NE-SW at $(10,245)$ (Fig. 2a).

\section{Hanging wall rocks}

The Chester Mountains, $24 \mathrm{~km}$ to the south consist of Ford Granodiorite of Devono-Carboniferous age (Weaver et al., 1991), cut by sparse m-scale dikes of dolerite and two-mica granite that have Cretaceous cooling ages $\left({ }^{40} \mathrm{Ar}{ }^{39} \mathrm{Ar}\right.$ ages 146 to $96 \mathrm{Ma}$; Richard et al., 1994; Siddoway et al., 2005). The unmetamorphosed hornblende-biotite granodiorite has a mediumgrained, inequigranular hypidiomorphic texture, and lacks visible penetrative fabrics. It is cut by pervasive minor brittle faults and shears marked by chloritic or oxidized surfaces (Fig. 3a). The mesoscopic faults are discrete, striated planes with an exposed trace length of 2 to $>25 \mathrm{~m}$ and spacing of 1 to $10 \mathrm{~m}$. On many faults, chloritic fine crush microbreccia (gouge) forms a layer 2 to 5 $\mathrm{mm}$ thick. Shear fractures have surface polish or a thin, mineralized veneer. Markers for offset are ordinarily absent in Ford Granodiorite; consequently, secondary fractures (Fig. 3a) or risers formed by fibrous mineral deposits (quartz and chlorite \pm epidote) were used for kinematic interpretation (Petit, 1987). The majority of shear planes strike ENE-WSW and dip SSE; but dips to NNW on conjugate planes were also measured (Figure 4a). The dominant shear sense is normal dextral oblique upon dip-slip oblique striae that trend SSW-NNE. Kinematic data indicate a principal extension (T) direction of $(19,003)$, and a shortening $(\mathrm{P})$ direction of $(60,232)$ (Fig. 4a). 


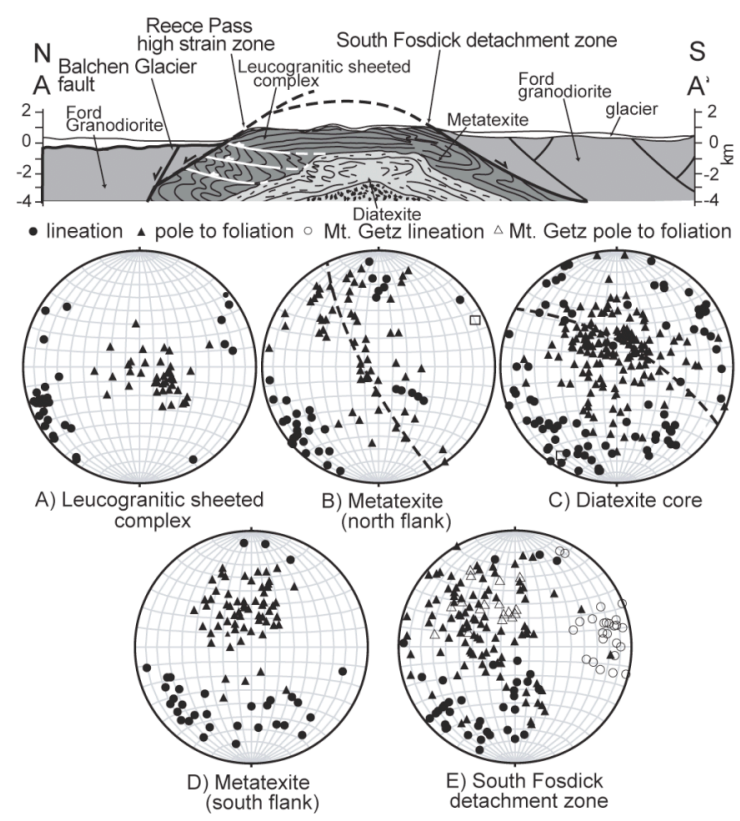

Figure 2. North-south cross section of the Fosdick Mountains migmatite dome with no vertical exaggeration. The subsurface geology is constrained from cliff exposures west of the cross section line, where deeper rocks have been exhumed. Equal area stereographic diagrams display poles to foliation and mineral lineations from the footwall of the Fosdick Mountains migmatite dome. Stereographic diagrams were prepared using Stereonet v. 6.3.3X, academic version, by R.W. Allmendinger. The filled circles are the mineral lineations and the filled triangles are poles to metamorphic foliation. To differentiate shear zone data of the South Fosdick detachment (E) from Mt. Getz and Mt.

Richardson, Mt. Getz mineral lineations are open circles and poles to metamorphic foliation are open triangles. The dashed lines are pi-circle girdles and the open rectangles are the pi-axis, or fold axis.

\section{The South Fosdick detachment zone}

The South Fosdick detachment (SFD) is a transitional zone of melt-present to solid-state deformation that is mapped at Mt. Richardson, the un-named ridge East of Mt. Getz, Mt. Getz, and southern Mt. Iphigene (Fig.1). The shear zone generally dips 20 $45^{\circ}$ to the $\mathrm{SE}$, deforms granodiorite and paragneiss units, and exposes a progression of overprinting structures from

extensional shear bands containing anatectic granite, mylonitic fabrics, to penetrative brittle structures.

There is also a zone of solid-state deformation on the northern flank of the Fosdick Mountains migmatite dome. This shear zone, referred to as the Reece Pass high strain zone (Siddoway et al., 2004), has been observed in the field and has a top-to-the-N sense of shear. The relationship between the South Fosdick detachment zone and the Reece Pass high strain zone is currently being investigated (Fig. 2).

\section{Extensional detachment structures in the presence of melt}

The southern Mt. Richardson segment of the SFD has a penetrative metamorphic foliation that has an ENE-WSW strike and a steep SE dip. The shear zone is intruded by syntectonic granite incorporated in extensional structures that exhibit presence of melt, such as extensional shear bands and inter-boudin regions that are leucosome-filled (Fig. 3b). The shear bands define two broad groups that are either oblique (at an angle of $\sim 20^{\circ}$ ) or at a high angle $\left(\sim 70^{\circ}\right)$ to the metamorphic foliation. Synthetic top-tothe-SW shear bands predominate; with antithetic top-to-the-NE shear bands occurring rarely. The shear bands range in length from $10 \mathrm{~s}$ of centimeters to $10 \mathrm{~s}$ of meters, and they are commonly 1 to $10 \mathrm{~cm}$ in width. These shear bands define an extension direction (T) of $(13,028)$, and a shortening direction (P) of (61, 273) (Fig. 4b). Melt-enhanced deformation is also manifest as sigmoidal boudins of biotite granodiorite host rock surrounded by leucogranite within shears, with the boudins' asymmetry recording top-to-the-SSW simple shear deformation.

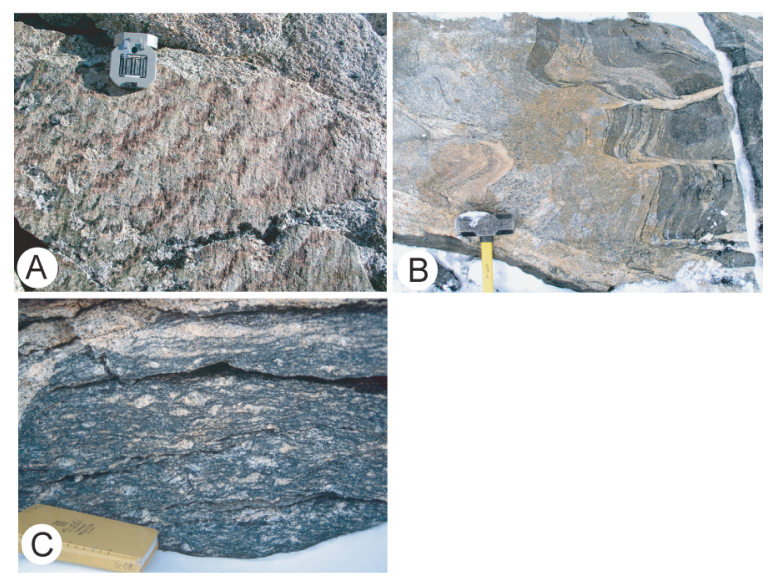

Figure 3. (A) Photograph of a brittle shear from the Chester Mountains hanging wall block. The orientation of the plane is $(257,48)$ with dip slip striae. Secondary PT structures (Petit, 1987) corresponding to the smooth-rough texture indicate normal shear sense. (B) Photograph of extensional leucosome-filled synthetic top-to-the-SW shear bands in the SFD shear zone from Mt. Richardson. (C) Photograph of S-C fabrics and asymmetric sigmoidal feldspar porphyroclasts that define sense of shear for mylonitic fabrics in the SFD.

\section{Mylonitic detachment}

The mylonitic portion of the SFD is well exposed at central Mt. Richardson and Mt. Getz. The SFD is an L $>S$ tectonite. The mylonitic gneisses have a pervasive foliation and a lineation defined by stretched quartz and biotite grains. S-C fabrics and asymmetric sigma porphyroclasts of feldspar indicate top-to-theSW to -WSW kinematic sense (Fig. 3c). In thin section, quartz grains are crystal-plastically deformed displaying dynamic recrystallization and development of a strong crystallographic preferred orientation. Feldspar porphyroclasts display internal micro-fracturing and recrystallization of feldspar, forming core and mantle structures.

The southern Mt. Richardson segment that is intruded by leucogranite has a steep mylonitic foliation, whereas the mylonitic foliation in the central Mt. Richardson and Mt. Getz segments dips shallowly. Syntectonic leucogranite emplaced within structural sites is as young as $102.4 \pm 0.7 \mathrm{Ma}$ (U-Pb zircon; Siddoway et al., 2006). The Mt. Richardson mylonitic fabrics have an orientation of $(060,65)$ (strike, dip) with a quartz and 
biotite stretching lineation of $(15,235)$. The Mt. Getz mylonitic fabrics have an orientation of $(040,35)$ and a biotite stretching lineation of $(12,080)$ (Fig. 2e). Lineations are oblique to strike of the solid-state fabrics and to the detachment zone, and reflect normal oblique dip slip.

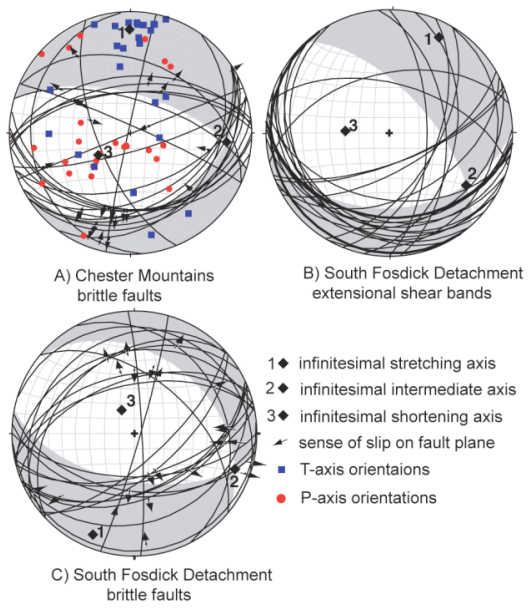

Figure 4. (A) Brittle shears of the Chester Mountains. (B) Extensional shear band data from the SFD (C) Brittle shears of Mt. Richardson. Kinematic solutions were calculated with the FaultKin 4.3.5 application, by R. W. Allmendinger.

\section{Brittle structures associated with detachment zone}

Mylonitic and migmatitic gneisses at Mt Richardson are cut by a conjugate array of moderately dipping mesoscopic brittle shear fractures (Fig. 4c). They strike NE-SW and exhibit normal dip-slip to normal oblique-slip striae corresponding to stretched quartz and chloritic streaks. Shear fracture analysis indicates (T) and $(\mathrm{P})$ axes oriented $(11,202)$ and $(72,331)$, respectively (Fig. $4 c)$.

\section{Timing of detachment tectonics}

We present U-Pb SHRIMP data (Fig. 5) for two Fosdick migmatite dome samples from the SFD (Fig. 1): (1) an equigranular biotite granite from a top-to-the-SW oblique synthetic shear band (sample M5-R136B; S 76 32.877 , W $144^{\circ}$ 41.248) from Mt. Richardson and (2) a medium-grained biotite granite dike (sample M5-G174; S 76 33.237 , W $145^{\circ} 12.055$ ) that crosscuts the mylonitic fabric of Mt. Getz and has a weak magmatic foliation.

The U-Th-Pb isotopic analyses were made using the SHRIMP II at the Research School of Earth Sciences, The Australian National University, Canberra, Australia, following procedures given in Williams (1998). The U/Pb ratios have been normalized relative to a value of 0.0668 for the Temora reference zircon (Black et al., 2003).

Zircon grains of the biotite granite are predominantly euhedral prismatic grains with bipyramidal terminations. Cathodoluminescence images of the grains reveal oscillatoryzoned cores and high $U$ rim overgrowths. Analyses of rim and core domains $(\mathrm{N}=15)$ display no discernible distinction and give Cretaceous ages between ca. 118-104 Ma. Cretaceous rim and core domain analyses $(\mathrm{N}=11 ; 2 \sigma$ limit) yield a weighted mean ${ }^{206} \mathrm{~Pb} /{ }^{238} \mathrm{U}$ age of $107.3 \pm 0.9 \mathrm{Ma}(\mathrm{MSWD}=0.60)$.

The granitic dike contains euhedral to subhedral zircon grains that are predominantly prismatic with bipyramidal terminations. Under cathodoluminescence, the cores are oscillatory-zoned and strongly luminescent, whereas the rim overgrowths are weakly luminescent (Fig. 5B). Analyses of core and $\operatorname{rim}(\mathrm{N}=25)$ domains have a wide scatter of Paleozoic ages, but eleven analyses yielded Cretaceous ages that define a group of ages at ca. 107-95 Ma with no systematic difference between core and rim analyses. Six of these analyses were discarded because they fall more than three sigma from the mean, thus the sample $(\mathrm{N}=5)$ yields a mean ${ }^{206} \mathrm{~Pb} /{ }^{238} \mathrm{U}$ age of $96.1 \pm 1.4 \mathrm{Ma}$ (MSWD $=0.53 ; 2 \sigma$ limit).

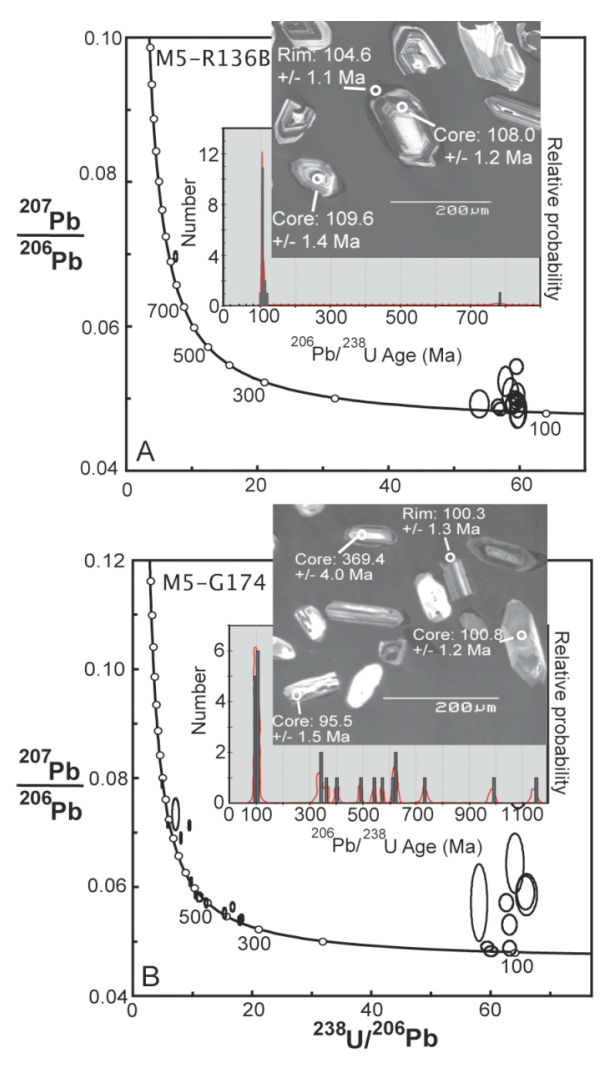

Figure 5. (A-B) Uncertainties given for individual analyses (ratios and ages) are at the one sigma level. Tera-Wasserburg (1972) concordia plots and weighted mean ${ }^{206} \mathrm{~Pb} /{ }^{238} \mathrm{U}$ age calculations were carried out using ISOPLOT/EX (Ludwig, 2003). The "Mixture Modelling" algorithm of Sambridge and Compston (1994), via ISOPLOT/EX, was used to un-mix statistical age populations or groupings; from these groups weighted mean ${ }^{206} \mathrm{~Pb} /{ }^{238} \mathrm{U}$ ages were calculated and the uncertainties are reported as $95 \%$ confidence limits. Insets are frequency distribution plots and cathodoluminescence images with labeled, calibrated but uncorrected for common $\mathrm{Pb}$, analysis spots for representative grains and rims. (A) Biotite granite from extensional shear band (M5-R136B). (B) Biotite granite dike of Mt. Getz (M5-G174). 


\section{Discussion and summary}

The high-grade migmatitic rocks of the Fosdick Mountains dome display $\mathrm{cm}$ - to $\mathrm{km}$-scale folds, high-temperature (sillimanite, biotite) stretching lineations, and leucogranite-filled extensional shear bands and inter-boudin regions. The hanging wall in the Chester Mountains comprises unfoliated plutonic rocks penetrated by brittle faults. The detachment zone exposes leucosome-filled extensional structures (shear bands, inter-boudin regions) and mylonitic stretching lineations, overprinted by brittle faults. We interpret the presence of these fabrics and structures to indicate a temporal and spatial transition from melt-present to solid-state deformation in the detachment zone that likely occurred during movement on the shear zone and translation of dome rocks toward shallow crustal levels. The geometrical and kinematic consistency of fabrics and structures in the footwall, hanging wall, and detachment zone indicate a linked deformational history that involved exhumation of the high-grade core by oblique detachment tectonics. The Chester Mountains block was translated down and to the west with respect to dome rocks. The dextral sense of translation is consistent with previous interpretations of dextral transtension in the broader region of the Ford Ranges (Siddoway et al., 2005; Luyendyk et al., 2003).

The NE-SW fold axes and mineral stretching lineations in the high temperature footwall are sub-parallel to NE-SW to ENEWSW mylonitic stretching lineations in the SFD (Fig. 2b-d), whereas the stretching axis from extensional shear bands is oriented more NNE-SSW (Fig. 4b). The infinitesimal extensional strain axes determined from brittle shear fractures, which overprint mylonitic fabrics at Mt. Richardson and form brittle shear fractures cutting non-metamorphosed plutonic rocks of the Chester Mountains, also trend SSW (Fig. 4c). The SSW orientation is parallel to fold axes of concentric folds overprinting the mylonitic shear zone and to the stretching direction from late tensile structures throughout the dome (shear bands and dike arrays: Richard, 1992; Siddoway et al., 2005). The change in orientation of stretching axes from ENE-WSW during migmatization and melt-present deformation to NNE-SSW after the transition to solid-state deformation may be a consequence of upward translation of the dome and strain partitioning between footwall and hanging wall during tectonic exhumation; or of a rotation in strain axes due to changes in plate boundary configuration. These hypotheses are being investigated presently.

A U-Pb age of $107.3 \pm 0.9$ Ma obtained for igneous zircon within granite emplaced in an extensional shear band within the detachment shear zone indicates that anatexis and melt-present deformation was underway at that time. A younger age limit on shear zone deformation is provided by the U-Pb age of $96.1 \pm 1.4$ Ma for igneous zircon from the granite dike that crosscuts mylonitic gneisses at Mt. Getz. These zircon data establish the syn- to post-deformational history for the SFD, and corroborate prior U-Pb monazite ages from syn- to post-tectonic granites in the Fosdick Mountains (106 \pm 1 Ma and $99.8 \pm 1 \mathrm{Ma}$; Richard et al., 1994). The new U-Pb zircon data establish the timing of partial melting and onset of tectonic exhumation of the Fosdick Mountains migmatite dome in a wrench setting (Luyendyk et al., 2003; Siddoway et al., 2005) during intracontinental extension along the actively extending Gondwana margin in Marie Byrd
Land - New Zealand - Campbell Plateau (Spell et al., 2000, and references therein; Tulloch and Kimbrough, 2003; Crampton et al., 2004; Scott and Cooper, 2005).

Acknowledgements. Work supported by National Science Foundation-Office of Polar Programs grants NSF-OPP 0338279 to Siddoway and NSF-OPP 0337488 to Teyssier. This manuscript has been improved greatly from recommendations by Andy Tulloch and an anonymous reviewer. Thanks to mountain guides Mike Roberts, Allen O'Bannon, and Forrest McCarthy. Thanks to employees of Raytheon Polar Services (Berg Field Center and USAP Cargo in particular); ANG $109^{\text {th }}$; Kenn Borek Air crews; and Chuck Magee and Barbara Armstrong (PRISE-ANU).

\section{References}

Black, L. P., S. L. Kamo, C. M. Allen, J. N. Aleinikoff, D. W. Davis, R. J. Korsch, and C. Foudoulis (2003), TEMORA 1: a new zircon standard for Phanerozoic U$\mathrm{Pb}$ geochronology, Chemical Geology, 20, 155-170.

Brown, M. (1994). The generation, segregation, ascent and emplacement of granite magma: the migmatite-to-crustally-derived granite connection in thickened orogens, Earth-Science Reviews, 36, 83-130.

Crampton, J. S., A. J. Tulloch, G. J. Wilson, J. Ramezani, and I. G. Speden (2004), Definition, age, and correlation of the Clarence Series stages in New Zealand (late Early to early Late Cretaceous), New Zealand Journal of Geology and Geophysics, $47,1-19$.

Fitzgerald, P. G., and S. L. Baldwin (1997), Detachment fault model for the evolution of the Ross Embayment, in Ricci, C.A., ed., The Antarctic Region: Geological Evolution and Processes, Terra Antarctica Publication, Siena, 555-564.

Flowers, R. M., S. A. Bowring, A. J. Tulloch, and K. A. Klepeis (2005), Tempo of burial and exhumation within the deep roots of a magmatic arc, Fiordland, New Zealand, Geology, 33, 17-20.

Kula, J., A. Tulloch, T. L. Spell, and M. L. Wells (2007), Two-stage rifting of Zealandian-Australia-Antarctica: Evidence from ${ }^{40} \mathrm{Ar}{ }^{\beta 9} \mathrm{Ar}$ thermochronometry of the Sisters shear zone, Stewart Island, New Zealand, Geology, 35, 411-414.

Ludwig, K. R. (2003), User's manual for Isoplot/Ex, Version 3.0, A geochronological toolkit for Microsoft Excel, Berkeley Geochronology Center Special Publication. Berkeley, CA.

Luyendyk, B. P., D. S. Wilson, and C. S. Siddoway (2003), Eastem margin of the Ross Sea Rift in western Marie Byrd Land, Antarctica: Crustal structure and tectonic development, Geochemistry, Geophysics, Geosystems, 4, 1090, doi:10.1029/2002GC000462.

Mehnert, K. R. (1968), Migmatites and the Origin of Granitic Rocks, Amsterdam: Elsevier

Pankhurst, R. J., S. D. Weaver, J. D. Bradshaw, B. C. Storey, and T. R. Ireland (1998), Geochronology and geochemistry of pre-Jurassic superterranes in Marie Byrd Land, Antarctica, Journal of Geophysical Research, 103, 2529-2547.

Petit, J. P. (1987), Criteria for the sense of movement on fault surfaces in brittle rocks, Jounral of Structural Geology, 9, 597-608.

Richard, S.M. (1992), Structure and Cooling History of the Fosdick Metamorphic Complex, Marie Byrd Land, West Antarctica, in Recent Progress in Antarctic Earth Science, edited by Y. Yoshida et al., Terra Scientific Publishing, Tokyo, p. 289-294.

Richard, S. M., C. H. Smith, D. K. Kimbrough, P. G. Fitzgerald, B. P. Luyendyk, and M. O. McWilliams (1994), Cooling history of the northem Ford Ranges, Marie Byrd Land, West Antarctica, Tectonics, 13, 837-857.

Sawyer, E. W. (1994), Melt segregation in the continental crust, Geology, 22, 1019 1022.

Siddoway, C. S., S. M. Richard, C. M. Fanning, and B. P. Luyendyk (2004), Origin and emplacement of a middle Cretaceous gneiss dome, Fosdick Mountains, West Antarctica, in Gneiss Domes in orogeny, edited by D. L. Whitney, C. Teyssier, and C. S. Siddoway, Boulder, Colorado, GSA Special Paper 380, 267-294.

Siddoway, C. S., L. C. III Sass, and R. P. Esser (2005), Kinematic history of the Marie Byrd Land terrane, West Antarctica: Direct evidence from Cretaceous mafic dykes, in Terrane Processes at the Margin of Gondwana, edited A. Vaughan, P. Leat, and R. J. Pankhurst, Geological Society of London, Special Publication 246, 417-438.

Siddoway, C. S., C. M. Fanning, S. C. Kruckenberg, and S. C. Fadrhonc (2006), U$\mathrm{Pb}$ SHRIMP investigation of the timing and duration of melt production and migration in a Pacific margin gneiss dome, Fosdick Mountains, Antarctica, Eos Trans. AGU, 87 (52), Fall Meet. Suppl., abstract V23D-0661.

Scott, J. M., and A. F. Cooper (2006), Early Cretaceous extensional exhumation of the lower crust of a magmatic arc: Evidence from the Mount Irene Shear Zone, Fiordland, New Zealand, Tectonics, 25, TC3018, doi: 1029/2005TC001890. 
Spell, T. L., I. McDougall, and A. J Tulloch (2000), Thermochronological constraints on the breakup of the Pacific Gondwana margin: The Paparoa metamorphic core complex, South Island, New Zealand, Tectonics, 19, 433-451.

Storey, B. C., P. T. Leat, S. D. Weaver, J. D. Pankhurst, and S. Kelley (1999), Mantle plumes and Antarctic-New Zealand rifting: Evidence from mid-Cretaceous mafic dykes, Joumal of the Geological Society, 156, 659-671.

Tera, F., and G. Wasserburg (1972), U-Th-Pb systematics in three Apollo 14 basalts and the problem of initial $\mathrm{Pb}$ in lunar rocks, Earth and Planetary Science Letters, $14,281-304$.

Tulloch, A. J., and D. L. Kimbrough (1989), The Paparoa metamorphic core complex, New Zealand: Cretaceous extension associated with fragmentation of the Pacific margin of Gondwana, Tectonics, 8, 1217-1234.

Tulloch, A. J., and D. L. Kimbrough (2003), Paired plutonic belts in convergent margins and the development of high $\mathrm{Na}, \mathrm{Al}, \mathrm{Sr}$, low $\mathrm{Y}$ magmatism: the Peninsular Ranges Batholith of California and the Median Batholith of New
Zealand, in Tectonic evolution of the northwestern Mexico and the southwestern USA, edited by S. E. Johnson, S. R. Paterson, J. Fletcher, G. H. Girty, D. L. Kimbrough, A. Martin-Barajas, Boulder, Colorado, GSA Special Paper 374, 275 295.

Weaver, S. D., C. J. Adams, R. J. Pankhurst, and I. L. Gibson (1992), Granites of Edward VII Peninsula, Marie Byrd Land: anorogenic magmatism related to Antarctic-New Zealand rifting, Transactions of the Royal Society of Edinburgh, 83, 281-290.

Wilbanks, J. R. (1972), Geology of the Fosdick Mountains, Marie Byrd Land, in Antarctic Geology and Geophysics, edited by R. J. Adie, Oslo, Universitetsforlaget, 277-284.

Williams, I. S. (1998), U-Th-Pb Geochronology by Ion Microprobe, in Applications of microanalytical techniques to understanding mineralizing processes, edited by M. A. McKibben, W. C. Shanks III, W. I. Ridley, Reviews in Economic Geology, 7, 1-35. 